\title{
Global Leadership and Diversity
}

Maryam Hassanzadeh

maryam_h7777@yahoo.com

\author{
Prof. Dr. Abu Daud Silong
}

abudaud.silong@gmail.com

\author{
Associate Prof. Dr. Azizan Asmuni \\ Dr. Nor Wahiza Abd Wahat \\ Department of Professional Development and Continuing Education, Faculty of Educational Studies \\ Universiti Putra Malaysia
}

Doi:10.5901/jesr.2015.v5n3p161

\begin{abstract}
The emergence of globalization and diversity brings out new demands for leaders. They should become global leaders who develop new skills and abilities to lead in multicultural environments. This paper discusses how to develop global leadership with a different set of competencies in diverse situations. After reviewing the related literature, the researchers conclude that the diverse environments such as multiculturalism have a significant influence on the development of global leadership. This paper is based on a research conducted using a qualitative method involving in-depth interviews of selected participants. The data collected is transcribed verbatim and categorized into themes. The research will attempt to answer the questions: 1) What is global leadership? 2) What are the competencies needed by global leaders to lead in diversity? 3) How are these competencies developed for global leaders? Based on the findings recommendations are put forward to improve the effectiveness of global leadership.
\end{abstract}

Keywords: global leadership, diversity, multiculturalism

\section{Introduction}

Going to the future Malaysia will intensify its efforts to become a developed nation through its national vision of 2020. One of the major initiatives being put into place to achieve this vision is the introduction of the New Economic Model (NEM) (NEAC, 2010). The New Economic Model explores the transformation of Malaysia from a middle-income to a higher-income nation. This model, as indicated in Figure 1, identifies that Malaysia needs an innovation-driven knowledge economy (k-economy) to achieve higher income status in the future. Thus, to achieve its vision 2020, Malaysia requires the economy to be transformed from being factor-driven to efficiency-driven and finally to a knowledgedriven k-economy. Talent and human capital development is the key to developing a k-economy (Gazali Abas, 2011). Also, to achieve vision 2020 the country needs a new type of leaders that can operate on the global stage.

Leadership is about influence and to influence a leader must have followers and the process of influencing occurs in a context towards some kind of goals (Abu Daud Silong, 2009). After reviewing the literature covering more than 100 years on leadership, it is found that there are many definitions developed by various scholars and researchers on the term, 'leadership'. More recent emerging ideas in leadership are on global leadership. This leadership thinking can be considered as the future model of leadership. Global leadership can be defined as the style of a leader who operates on the global stage with a global mindset in an environment that is complex and diverse. Also, to be successful global leaders they need new competencies. Freshwater (2014) noted "Basically, the term refers to an organization's leadership talent who work across geographic and cultural boundaries". Hui (2013) introduced global leaders as "...leaders who have unique skills to lead diverse employees and understand different countries' legal systems and business operations". Conger, and O'Neill (2012) identified global leadership as "...organization's leadership talent who work across geographic and cultural boundaries". In reviewing the global leadership definition we can highlight multiculturalism as a 
key element of globalization (Caligiuri 2012, 2006; Mendenhall et al., 2012, and Ket de Varies, 2005).

Osland and Brid (2006) identified "Global leaders influencing the thinking, attitudes, and behaviors of a global community to work together synergistically towards a common vision and common goals" (p.123). Thus global leaders have to work with people who are culturally diverse and geographically dispersed.

This study aims to understand global leadership based on the literature and also the competencies for global leaders in diversity based on data collected from in-depth interviews of selected participants. Finally, suggestions are made for the development of those competencies.

\section{Figure 1}

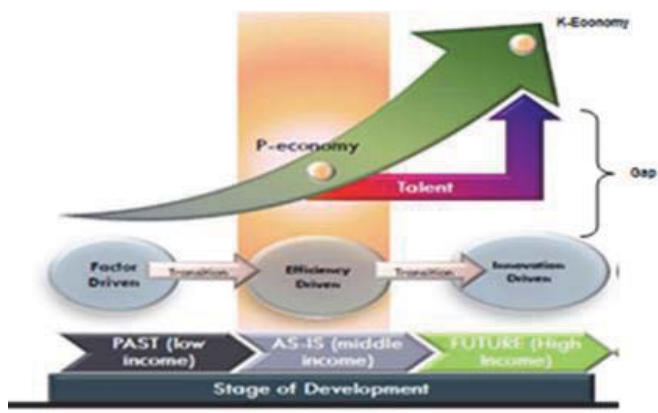

Figure 1: Malaysia's New Economic Model

Source: Ghazali, 2011

\section{Literature Review}

The literature review covers topics such as globalization and diversity, leadership and global leadership, leading in globalization, cross-cultural competencies, and developing global leaders.

\subsection{Globalization and diversity}

"At the end of twenty century, concern with globalization and its seemingly continuous intensification led to a new stream of research in organizational studies focusing on the change that globalization brings to organizations" (Bhagat, R \& Steers, R., 2009, p.148). Globalization knowledge and its effects are gained from a variety of perspectives from psychologists (Shokef \& Erze, 2006; Earley, Ang \& Tan, 2006; Erze \& Gati, 2004), ethnographers (Soderberg \& Varaa, 2003; Ailon-Suadi \& Kunda, 2003) and sociologists (Drori, Meyer \& Hwang, 2006).

Globalization is changing our world today. Advances in technology, mass communication, business, human rights violations, and education are the forces of change. The importance of exchanging information leads people to work together but those who work together as a team face challenges such as differences in language, values, beliefs, cultures, and religions. In the age of globalization leadership is intertwined with culture. Kessler and Wong-Ming (2009) refer to the simultaneous blending and clashing of cultures and the eventual emergence of an amalgamated and apparently omnipresent dynamics of associations and conflicts".

"Institutional and cultural characteristics of the global world influence the structure and culture of global work organizations and the mindset and self-identity of individuals situated in them" (Bhagat, R \& Steers, R., 2009, p.148). The theme of globalization merely refers to exchange and change through exchange economics and politics (Bartelson, 2000) and has less focus on cultural features.

Diversity means differences in color, gender, ability, sexual orientation, religion and age. Diversity is not only about difference in culture but also about differences in decision making or encouraging people. Robert et al. (2007) explain that in diversity we reflect on the way people handle their universal problems of human nature such as the relationship between humans and Nature, time, behavior, and relationship - reflecting how individual cultures find their own 
distinctive solutions.

As we mentioned early, diversity is not only about differences in color and gender, but also about people with different interpretations of the act. For example, Tein (1998) says "it so eloquent when he states that people in this country tend to perceive European accents to be more prestigious. However, people with Latino and Asian accents are perceived to be ignorant, uneducated and unequal" (p.39). Another example provided by Hilton (2007) says that diversity is that "Chinese clients hate to include a quote from a spokesperson in their press releases because it is seen as giving undue credit to that person: on the other hand, international journalists, especially British and American ones, will not publish a story without a quote" (р.35). A very simple element can play a big role in diverse organizations. Thus, global leaders should develop multiple-pronged knowledge about their members.

Hughes et al. (2002) mentioned that a leader can be effective when leading with emotion and thinking rationally at the same time. Referring to the above idea we can identify the importance of relationship between leader and followers, which can be termed as cultural skills. It is also referred to as cultural intelligence or CQ (Cultural Quotient). Peterson (2004) defines CQ as skills such as language and qualities such as tolerance and flexibility in diversity. Leaders on the global stage have to be aware of different "baggage" people bring into an organization. A person in the process of globalization will be transformed from intra-culture and inter-culture to cross-culture, which is the key challenge for a global leader. Yulk (2002) mentioned the importance of understanding people from different cultures and how they interpret the actions of a leader.

\subsection{Leadership and global leadership}

In the $19^{\text {th }}$ and $20^{\text {th }}$ centuries, leadership theories can be summarized into three major ideas - the traits theory, behavioral theory, and the situational leadership theory. The traits theory initially believed that leaders were born but later studies indicated that these traits can be acquired. Therefore, certain traits that are important in effective leadership can be learnt. However, observing and measuring traits are not that simple. Thus, later researchers started to examine behaviors in their leadership studies such as those conducted by the University of lowa, University of Ohio and University of Michigan. They basically noted various styles of leadership exhibited by leaders. Also included in the behavioral studies of leadership are roles played by leaders, conducted by Mintzberg and Yukl (Abu Daud Silong, 2009).

Some researchers, who were not very happy with the traits and behavioral studies, began to examine the situational or contingency leadership theories. They concluded that there is no one style of effective leadership but it depends on situations (Fiedler, 1967 and House \& Mitchell, 1974). Thus, to be effective a leader must match his/her leadership style with the leadership situation.

Moving towards the end of the $20^{\text {th }}$ century and coming to the $21^{\text {st }}$ century, emerging leadership theories and ideas were explored. Among the prominent theories are the transactional-transformational leadership theory introduced by Burn (1978) and servant leadership introduced by Greenleaf (1977). They are more integrative leadership ideas compared to previous traditional traits, behavioral and situational theories.

A more recent emerging idea in leadership is global leadership. This leadership thinking can be considered as the future model of leadership. As shown in Figure 2 ideas in leadership started from traits theory, behavioral theory, and situational theory and moved to the transactional-transformational and servant leadership theories. The next leadership theory or idea is more focused on global leadership. Thus it is more of a recent phenomenon. It began to appear in the literature in the early 1990s. The earliest published literature on global leadership was in 2001 (Ducker, 2012). Basically, "Global leadership is relatively a new concept, a fact that is testified by the lack of an established definition, a paucity of field research and limited methodological sophistication" (Ducker, 2012).

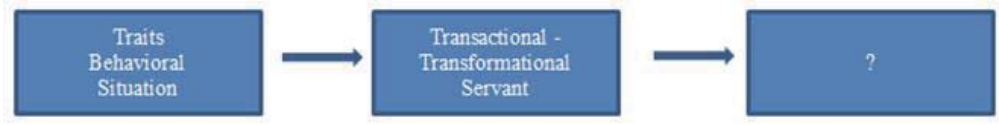

Figure 2: Past, current and future leadership theories

Osland and Brid (2006) believe that global leadership "differs from domestic leadership in degree, in terms of issues related to connectedness, boundary spanning, complexity, ethical challenges dealing with tensions and paradoxes, pattern recognition, community and leading large-scale change efforts across diverse cultures" (p. 123). 


\subsection{Leading in globalization}

Caligiuri (2013) stated that the present and future global environment and workplace "need leaders who are able to effectively manage in complex global environments, who are able to negotiate cultural challenges and conflicts, and who understand seemingly conflicting regulatory requirements, unexpected costs, and diverse stakeholders in foreign countries" (p.176).

It is critical for global leaders to understand how their behaviors appear in the eyes of their followers. To do that there is an urgent need to understand cross-cultural differences. She also mentioned that those global leaders who have available cultural responses can work effectively with colleagues from different cultures. Alire (2008) also supported the idea of being effective in diverse organizations "... is largely dependent on the extent to which they have the respect of those they seek to lead" (p. 101).

Global leadership is about leading diverse people in complex environments. To deal with people global leaders need to know about the background of people such as their beliefs, values, religions and their sensitivity. To do that global leadership requires cultural understanding.

Culture is people understanding the importance of interacting with their environment over a period of time. People carry their own culture to their workplace. Thus, harmony among cultures in a multicultural organization is the art of global leaders.

\subsection{Cross-cultural competencies}

Dickson et al. (2003) explained that different cultural environments need different leadership behaviors. To do that, leaders need to have Cultural Intelligence (CQ), which is described as a person's ability to successfully adapt to new cultural settings, that is, unfamiliar settings associated with different cultural contexts (Earley \& Ang, 2003). On the other hand, a group of researchers believe that cultural intelligence is not only about adapting to the new culture but also dealing effectively with diversity (Ang \& Van Dyne, 2008; Earely \& Ang, 2003). According to Earley and Ang, three elements are required for $\mathrm{CQ}$, which are cognition, motivation and behavior. Cognitive component refers to the ability to distinguish cultures based on different cultural cues. The motivational element is about self-motivation to adapt to a new cultural environment, while the behavioral element refers to the ability of a person to take the action needed.

Referring to the above discussion, when responding to cultural adaptation, leaders will adjust their behaviors based on the host culture norm. Cultural adaptation is vital to some functions such as sales, marketing or public relations more than others but all leaders in general need cultural adaptation in some part of their functions, which include the need to motivate, gain trust or influence followers. Earley and Ang (2003) emphasized the need for CQ in order to understand and act to adjust to the new culture environment.

\subsection{Developing a global leader}

With rapid globalization, there is recognition for more global leadership development. Currently there is a shortage of global leaders and this is acknowledged by most organizations. It has also been emphasized that:

The challenges of sourcing leadership talent are particularly salient in today's global economy. As your organization's operations expand across the world, they will demand a mobile pool of leadership talent. Yet our research suggests a surprising number of organizations are struggling with critical shortages of what we call global leaders (Conger, \& O'Neill, 2012 p.55).

Caligiuri (2006) identified KSAOs (knowledge, skills, abilities, other personality characteristics) for employees based on job task, and giving to the right people (those with the requisite KSAOs) the right development opportunities that will develop leaders who can work effectively on the global stage with a global task and activities. Thus, the chance is high to be a global leader for those who are culturally intelligent and believe themselves to be a part of the global task and are also able to integrate and appreciate diversity.

\section{Methods}

This exploratory study was conducted to identify cultural competencies for global leaders in diversity. It employed a qualitative approach using in-depth interviews for data collection. Eight participants were interviewed between September 2014 and February 2015. It involved selected participants who had served as top leaders of a selected university. 
This research is a qualitative study which collects data from experiences of the participants. An interview guide was developed based on previous research and secondary data. Also, one of the researchers interviewed herself as a person who had worked in a multicultural environment for seven years to test and develop the interview protocol. The interviews were conducted at the residence or office or premise as agreed by the participants.

The interviews lasted about two hours each and they were recorded with the permission of the participants. During the interviews the researchers, used field notes to capture the participants' feelings and non-verbal communication such as body language. The data from the interviews were transcribed verbatim. The researchers read the transcriptions many times to identify the codes, which were developed to categories the findings into various themes.

\section{Findings}

Based on the data analysis, the findings of the in-depth interviews are presented in Table 1. Based on the analysis of data, three major themes were identified that contribute to global leadership and diversity: cultural attitudes, cultural skills, and cultural knowledge..

Table 1: Cultural competencies, skill and knowledge for global leaders

\begin{tabular}{|l|l|l|}
\hline Cultural attitudes & Cultural skills & Cultural knowledge \\
\hline Understanding people & Skill to establish terms of behavior & Awareness \\
\hline Talking with different norms and using different strategies & $\begin{array}{l}\text { Skill to code switch } \\
\text { Problem Culture }\end{array}$ \\
\hline Do not judge people & Skill to communicate with different groups of people & Asking question \\
\hline Looking at people from their own perspectives & Skill to adapt to the new culture & Understanding human potential \\
\hline Sensitive to norms of others & Skill to use cultural gap potential & Knowing about a particular culture \\
\hline Flexible & Skill to localize HR to the local context & Understanding cultural influence \\
\hline Willing to work in a group (discussion) & Skill to apply cultural knowledge & Learning competencies \\
\hline Willing to accommodate women & Having skill development & Understanding cultural elements \\
\hline Ready to adopt new ways & Having integration & \\
\hline Respect people & Making awareness, knowledge and skill as part of behavior & \\
\hline Sensitive to multiculturalism & Skill to function in diverse environments & \\
\hline Willing to establish linkage & Building organizational culture based on various cultures & \\
\hline Understanding feelings of others (EQ) & \\
\hline Willing to talk to people & Balancing between diverse cultures & \\
\hline Sensitive to ethics and sub-ethics & Building cross-cultures with local elements & \\
\hline Looking for feedback & Giving opportunities to employees & \\
\hline & Able to network through social media & \\
\hline
\end{tabular}

\section{Discussion}

According to Kristof-Brown (2000), individual characteristics such as attitudes, skills and knowledge which are in congruence with the organizational environment, leads to positive organizational outcomes. Thus, leaders who operate in globalization to perform effectively with good outcomes need to expand their global competencies. Based on the findings of this study we present some characteristics which are required for leaders who are involved with globalization.

\subsection{Cultural attitudes}

Among all cultural attitudes EQ is ranked highest. Emotional Intelligence is "the ability to monitor one's own and others' feelings and emotions, to discriminate among them and to use this information to guide one's thinking and actions" (Salovey \& Mayer, 1990: p.189). Many scholars have indicated the relationship between EQ and leadership effectiveness (Boal, 2000; Day 2000; George, 2000; Goleman, Boyatzis \& McKee 2002; Hooijberg, Hunt \& Dodge, 1997; Kerr et al., 2006; Rosete \& Ciarrochi, 2005; Wong \& Law, 2002). Diversity is the result of globalisation. The factors such as education, overseas experiences, and human rights are the reasons for diversity. Thus, challenges for the global leader are to manage this diversity. $\mathrm{EQ}$ is not only to make the effective global leaders, but also is required to perform on the global stage.

As mentioned earlier, people carry their own cultural baggage to the organization. Thus, effective global leaders need to be sensitive to their norms, ethics and sub-ethics. It is their ability to understand and distinguish and respect peoples' cultures and emotions at the workplace and be able to switch codes based on different cultures that make them 
effective global leaders. To do that it is important to look at people from their own perspectives. After all, flexibility of global leaders helps them to adapt to the multicultural and unfamiliar environment. The findings of this study also indicate that global leaders who have EQ are successful in team working and communication skills.

\title{
5.2 Cultural skills
}

Among the findings of this study CQ ranked highest in the cultural skill theme. Cultural Intelligence (CQ) is 'a person's capability for successful adaptation to new cultural settings, that is, for unfamiliar settings attributable to cultural context' (Earley \& Ang 2003, p.9). There is a gap between cultures and global leaders with higher CQ are able to use this potential gap to improve the organization. Grouping people in the right place will increase the organizational performance. CQ plays important roles in the networking as well. Understanding the host countries' culture and adapting to their culture helps global leaders to have strong and long term networking.

On the other hand, global leaders need to be able to build their organizational culture with respect and be able to balance all differences. Having technological skills also is very important for global leaders. It does not mean a global leader should be an expert in programming and computer skills, but should be able to utilize new technology in the organization. It can help them to keep their networking and linkage through the media as well.

Ultimately, for those global leaders who are leading in their own countries but in a multicultural environment, it is important to build a cross culture, but with local elements and also to localize human resources to the local context.

\subsection{Cultural knowledge}

Alire (2008) believes leadership for diversity needs "knowledge of history and culture, evidence of supporting service and possible linguistic abilities" about different groups of people who work in an organization. (p. 101). Findings of this study highlighted cultural awareness not only of other cultures, but also our own culture to operate in the global arena. Asma Ahmad (1996), quoted culture awareness by two western and eastern philosophy gurus;

\begin{abstract}
Years of study have convinced me that the real job is not to understand foreign cultures but to understand our own. I am also convinced that all one ever gets from studying foreign cultures is a token understanding. The ultimate reason for such study is to learn more about how one's own system works

How can I talk of the sea to the frog when it has never left its pond? How can I talk of frost to the bird of the Summerland when it has never left the land of its birth? How can I talk to the sage when he is a prisoner of his own doctrine? (p. vii)
\end{abstract}

A global leader needs to understand the host culture elements and symbols such as "who are their heroes" and what are "their attires". Gaining cultural knowledge is not only necessary to improve the global leaders function, but also to help leaders to adapt easily into the new culture. On the other hand, global leaders need to gain knowledge about the problems which are the result of diversity. In this case, host countries' human resource department can help global leaders to be aware of organizational problems and how the culture affects their organizational performance.

\section{Conclusion, Implications and Recommendation}

In conclusion, global leaders are those who operate on the global stage in a complex and diverse environment. One of the key challenges is that they have to work with different groups of people and cultures. Thus they need multicultural attitudes, skills and knowledge to lead in diversity. Global leaders in multicultural organizations should "create an environment where no one is disadvantaged (or preferred) because of race, ethnicity, creed, gender, sexual orientation, etc" (Alire, 2008, p.101).

The research findings identified the importance of those competencies such as talking with groups of people with different norms and cultures and seeing them not from your own perspective but from theirs. The leaders when working in diversity have to apply cultural competencies such as EQ and CQ to make them more effective. They also have to possess skills and knowledge in leading diverse groups of followers. Some of the key skills identified include the ability to communicate with people of different backgrounds and able to adapt to new cultures. For knowledge, the leaders must be aware of self, cultures and problems when leading diverse groups.

From the discussion, we can imply that there are challenges faced by global leaders. They are forces of change as indicated by one of the participants such as "industrialization, westernization, modernist ion, globalization, technology 
and Islamization".

Based on the discussion, this paper makes some recommendations to improve global leadership in the context of leading in diverse situations. These include developing multicultural knowledge, skills and positive attitudes like sensitivity to other cultures when leading in diversity.

\section{References}

Abu, Daud Silong. (2009). Leadership theories, research and practices: Framing future leadership thinking. Inaugural Lecture Series, Serdang: Universiti Putra Publisher.

Ailon-Souday, G. and Kunda, G. (2003). "The local selves of global workers: the social construction of national identity in the face of organizational globalization". Organization Studies 24 (7): 1073-96.

Alire, C (2008). Diversity and leadership. Journal of Library Administration, 32: 3-4, 99-114.

Ang, S,. \& Van Dyne, L. (2008). Conceptualization of cultural intelligence. In S. Ang \& L. Van Dyne (Eds.), Handbook of cultural intelligence: Theory, measurement, and applications (PP. 3-15). Armonk, NY: M.

Asma Ahmad (1996). Going global cultural dimensions in Malaysian management. Malaysian Institute of Management.

Bartelson, J. 2000. "Three concept of globalization", International Sociology, 15 (2): 180-96.

Bhagat, R \& Steers, R (2009). Cambridge handbook of culture organizations, and work. Cambridge University Press 2009.

Boal, KB (2000), 'Strategic Leadership Research: Moving On', Leadership Quarterly, vol. 11, no. 4, p. 515.

Burns J. M. (1978). Leadership. New York: Harper \& Row.

Caligiuri, P. (2013). Developing culturally agile global business leaders. Organizational Dynamics, 42(2013) 175-182.

Caligiuri, P., Tarique, I. (2012). Dynamic cross-cultural competencies and global leadership effectiveness. Journal of World Business, 47(2012) 612-622.

Caligiuri, P. (2006). Developing global leaders. Human Resource Management Review, 16: 219-228.

Conger, J. A. and O'Neill, C. (2012). Building the bench for global leadership. People \& Strategy, 35 (2), 53-57.

Day, DV (2000). 'Leadership Development: A Review in Context', Leadership Quarterly, vol. 11, no. 4, p. 581.

Dickson, M.W., Den Hartog, D.N. and Mitchelson, J.K. (2003). " Research on leadership in cross-cultural context: making progress, and raising new questions", The Leadership Quarterly, Vol. 14 No.6, pp. 729-768.

Drori, G. S. Meyer, J. W., and Hwang, H. (eds.) (2006). Globalization and Organization: World Society and Organizational Change. Oxford: Oxford University Press.

Ducker, C. (2012). Global leadership - grasping a slippery term. Encounters Mission Journal, 39: 1-9.

Earley, P. C., Ang, S., Tan, J. S. (2006). "What is cultural intelligence and why does it matter?", in CQ: Developing cultural intelligence at work. Stanford, CA: Stanford University Press. Pp. 19-41.

Earley, P.C. and Ang, S. (2003), Cultural intelligence: Individual Interactions Across Cultures, Stanford University Press, Standford, CA.

Erez, M and Gati, E. (2004). "A dynamic. Multi-level model of culture: from micro level of individual to the macro level of world culture", Applied Psychology 53: 583-98.

Fiedler, F.E. (1967). A theory of leadership effectiveness. New York: McGraw-Hill.

Freshwater, D. (2014). Board editorial: The challenge of global leadership: managing change, leading movement. Journal of Research in Nursing, 19 (2), 93-97.

George, JM. (2000). 'Emotions and leadership: The role of emotional intelligence', Human Relations, vol. 53, no. 8, p. 1027.

Ghazali Abas. (2011). Talk on "Human Capital Development in Malaysia: Performance, challenges and way forward", International Workshop on HRM/HRD, 15 May 2011, Universiti Putra Malaysia.

Goleman, D, Boyatzis, RE \& McKee, A. (2002), The new leaders : transforming the art of leadership into the science of results, Little Brown, London.

Greenleaf, R. K. (1977). Servant leadership: A journey into the nature of legitimate power and greatness. New York: Paulist Press.

Hilton, G (2007). Becoming culturally fluent. Communication World, 34-36.

Hooijberg, R, Hunt, JG \& Dodge, GE 1997, 'Leadership Complexity and Development of the Leaderplex Model.' Journal of Management, vol. 23, no. 3, p. 375.

House, R.J, and Mitchell, T.R. (1974). Path-goal theory of leadership. Contemporary Business, 3 (Fall), 81-98.

Hughes, R.L, Ginnett, R.C. and Curphy, G.J. (2002), Leadership: Enhancing the Lessons of Experience, $4^{\text {th }}$ ed., McGraw-Hill, Irwin, Boston, MA.

Hui, D. (2013). Virtual global leadership model: exploratory research of leadership. Proceedings of $7^{\text {th }}$ Global Business and Social Science Research Conference. Beijing, China.

Kerr, R, Garvin, J, Heaton, N \& Boyle, E 2006, 'Emotional intelligence and leadership 86 effectiveness', Leadership \& Organization Development Journal, vol. 27, no. 4, pp. 265 - 79.

Kessler. E.H and Wong-Ming D.J. (2009), Cultural Mythology and Global Leadership. Cheltenham, UK.

Ket de Varies, M. F. (2005). Global executive leadership inventory. San Francisco: John Wiley and Sons.

Kristof-Brown, A. L. (2000). Perceived applicant fit: Distinguishing between recruiters' perceptions of person-job and personorganization fit. Personal Psychology, 53: 643-671.

Mendenhall, M. E., Reiche, B. S., Brid, A., \& Osland, J. S., (2012). Defining the global in global leadership. Journal of World Business, 
47(2012), 493-503

National Economic Advisory Council. (2010). New Economic Model for Malaysia, Part 1. Putajaya: Percetakan Nasional Malaysia Berhad.

Osland, J., \& Brid, A. (2006). Global leaders as experts. In Mobley, W., \& Weldon, E. (Eda.), Advance in Global Leadership 4 (2006), 123-142. Stamford, CT: JAI Press

Peterson, B. (2004), Cultural intelligence: A guide to working with people from other cultures, Intercultural Press, Yarmouth. ME.

Salovey, J.D. Mayer (1990). Emotional intelligence. Imagin, Cogn. Personal., 9 (3) (1990), pp. 158-211.

Robert, T.M., Philip, R.H., and Sarah V.M., (2007). Managing cultural differences, global leadership strategies for the $21^{\text {st }}$ century. $7^{\text {th }}$ ed., Linacre House, Jordan Hill, Oxford.

Rosete, D \& Ciarrochi, J (2005), 'Emotional intelligence and its relationship to workplace performance outcomes of leadership effectiveness', Leadership \& Organization Development Journal, vol. 26, no. 5.

Shokef, E. and Erze, M. (2006). "Global work culture and global identity as a platform teams", in B. Mannix, Neale, M., and Chen, Ya-Ru (eds.), National Culture and Groups: Research on Managing Groups and Teams, vol 9. San Diego, CA: Elsevier JAI Press, pp. 325-52.

Soderberg, A. -M. and Varaa, E. (2003). Merging Across Borders: People, Cultures, and Politics. Copenhagen: Copenhagen Business School press.

Tien, "challenge and opportunities," Library Journal 123 (September, 1998): 39.

Wong, C-S \& Law, (2002). 'The effects of leader and follower emotional intelligence on performance and attitude: An exploratory study', The Leadership Quarterly, vol. 13, no. 3, pp. 243-74.

Yulk, G. (2002), Leadership in Organizations, $5^{\text {th }}$ ed., Prentice Hall, Upper Saddle River, NJ. 